\title{
THE EFFECT OF COMPETITIVE ADVANTAGE ON FINANCIAL PERFORMANCE AND FIRM VALUE: EVIDENCE FROM INDONESIAN MANUFACTURING COMPANIES
}

\author{
Wijayanto A.* \\ Doctoral Candidate, Doctoral Program of Business Administration, \\ University of Brawijaya, Malang, Indonesia \\ Suhadak, Dzulkirom M., Nuzula N.F. \\ Doctoral Program of Business Administration, Brawijaya University, Malang, Indonesia
}

*E-mail: andibilt@gmail.com

\begin{abstract}
Many companies invest heavily in building competitive advantage to improve their financial performance and corporate value. This study aims to examine and explain the effect of competitive advantage on financial performance and firm value of manufacturing firms in Indonesia. The study was conducted on 30 manufacturing firms in Indonesia by analyzing the data on the company's financial statements of the period from 2010 to 2016. Data were analyzed using Generalized Structured Component Analysis (GSCA). The results conclude that competitive advantage has a positive and significant effect on financial performance and firm value. Financial performance also shows a significant and positive effect to firm value. This study provides empirical evidence of the effect of competitive advantage on firm value which is rarely studied before. This study also strengthens the evidence of the effect of competitive advantage on financial performance and the effect of financial performance on firm value.
\end{abstract}

\section{KEY WORDS}

Competitive advantage, accounting ratios, signaling theory, generalized structured component analysis, firm value.

The shareholders wealth maximization is the principal goal of financial managers in every business enterprise (Kaczmarek, 2014). To achieve these objectives, competitive advantage is believed to be an important factor determining financial performance (Cao, et al., 2014; Chahal \& Bakshi, 2014; Grant, 1991; Porter, 1985) and higher corporate values (Connelly et al., 2011; Ghosh and Ghosh, 2008; Standfield, 2005). Although some studies have been carried out on competitive advantage, few studies have investigated the effect of competitive advantage on firm value.

The effect of competitive advantage on financial performance is stated by Grant (1991) that the profitability of a company is determined by industry attractiveness and competitive advantage. However, Coff (1999) stated that competitive advantage does not always improve organizational performance but depends on how much revenue a stakeholder can enjoy. Newbert (2008) proves a positive and significant relationship between competitive advantage and organizational performance. Similar findings are also shown by the study of Gamero, et al. (2009); Kamukama, et al. (2011); Sungyuan \& Ussahawanitchakit (2015); and Zhou, et al. (2009).

The research that examines the relationship between competitive advantage and firm value is very rare. The research of Boasson et al. (2005) reported as one and only research which examines the effects of competitive advantage on firm value. However, Boasson et al. (2005) used geographically based sources of competitive advantage than the company's own competitive strength. This study contributes to filling the gap by examining the effect of competitive advantage based on resource-based (Barney, 1991; Wernerfelt, 1984) and nonresource based concepts (Porter, 1980) on the firm value. 
The relationship between financial performance and firm value is explained based on signaling theory. A good financial performance of a company will show the current state of the company and future growth potential. Positive signals that can be seen from the profitability of the company will be able to increase the company's stock price so as to contribute positively to firm value. Ghosh and Ghosh (2008) stated that profitability as one of the indicators of financial performance becomes one of the main factors that determine firm value.

The purpose of this study is to examine and explain the effect of competitive advantage on financial performance and firm value of manufacturing companies in Indonesia. The importance of the research on Indonesian manufacturing companies are: (1) the manufacturing sector is the driving factor of economic growth in Indonesia. By 2015, manufacturing industry performance reached Rp2,097.71 trillion or contributed $18.1 \%$ to national GDP; (2) since the implementation of Asean Economi Community, the competition of manufacturing industry among Asean countries has been increasing. Unfortunately, the competitiveness of Indonesia's manufacturing industry is quite weak. Based on the 2016 Global Manufacturing Competitiveness Index (GMCl), Indonesian manufacturing industry competitiveness in the Asean region was under Singapore, Vietnam, Malaysia and Thailand (Deloitte and US Council on Competitiveness, 2016). It is important for manufacturing companies in Indonesia to increase their competitive advantage so as to improve their financial performance and increase the value of the company.

\section{LITERATURE REVIEW}

Competitive Advantage. Competitive Advantage is a positional superiority condition where the company has a successful strategy, and difficult to replicate. Barney (1991) argues that the company has the competitive advantage if it implements the strategy of value creation that is not implemented simultaneously by the current competitors and potential competitors.

There are several theoretical conditions underlying competitive advantage, which are resource heterogeneity, ex post limits to competition, imperfect resource mobility, and ex ante limits to competition (Peteraf, 1993). The Heterogeneity Pillar shows that the underlying resource and capability bundle of production is inter-firm heterogeneous (Barney, 1991; Peteraf, 1993). Different resource acquisitions determine different levels of efficiency. The superior resources will enable the company to produce more economically to meet customer expectations. Pillar Ex Post Limits to Competition means there must be a power that can limit competition. This pillar can be achieved if it meets two conditions, namely imperfect imitability and imperfect substitutability. Ex Ante Limits to Competition means that in order to maintain competitive advantage, the heterogeneity of the resource must be maintained by keeping revenue above cost. Imperfect Mobility means that the resource can not be moved because it cannot be traded. This theoretical model is a resource-based model because it is based on organizational resources.

Various measurement methods formulated by experts to be able to measure the level of a company's competitive advantage. This study uses a method by Dickinson and Sommers (2012) to measure competitive advantage. According to Dickinson \& Sommers (2012), Competitive Advantage can be measured using resource-based indicators and market/industry-based (non-resource) indicators. Resource-based indicators are built on the concept of barriers to entry (Wernerfelt, 1984). It includes Economies of scale, product differentiation, Innovation, and Capital requirements. Non-resource indicators based on market/industry (Porter, 1980). It includes power over suppliers, power over customer and the credibility of the expected threat of Retaliation.

Economies of scale. Economies of scale enable companies to use resource capabilities (technology and manufacturing quality) to deliver products efficiently. Economies of scale is measured by Cost of Sales (CoS) ratio, which is cost of goods sold divided by net sales. The larger CoS ratios mean greater costs incurred to generate net sales. Vice versa. 
Product differentiation shows the company's ability to establish brand identities. It becomes a barrier for newcomers or existing competitors. Product differentiation is measured by the advertising intensity ratio (AdvInt) where advertising expense divided by net sales.

Innovation. Innovation reflects proprietary technology of the company. Companies that invest more in innovation (research and development as well as patents) will have higher future profitability if the projects implemented produce a positive net present value. Innovation is measured by the ratio between total research and development costs and patent amortization expenses divided by net sales.

Capital requirements. Barriers to entry exist if high levels of capital are required to compete within an industry. Capital requirements are measured by Capital intensity (Caplnt), defined as depreciation expense divided by net sales. Companies with higher levels of capital intensity will have higher returns if it effectively become barriers to entry for competitors.

Power over suppliers. Companies are able to build excellence by exerting power over suppliers to get favorable trading conditions. Power over suppliers are measured by: (1) operating liability leverage (OLLev) ratio, defined as the ratio of operating liabilities divided by net operating assets; and (2) inventory turnover, calculated by dividing the cost of goods sold by inventory.

Power over customers. The strength of the customer shows the company's competitive position. Companies have bargaining power over customers indicated by recurring transactions that indicate the limited product substitution. Power over customers are measured by: (1) receivables turnover, ie net sales divided by receivables; (2) Market share, ie sales revenue divided by industry revenues.

The credibility of expected threat of retaliation. Companies must be able to retaliate against newcomers or existing competitors. To achieve this condition, the company must have sufficient financial flexibility to engage in retaliation. The company has the ability to respond to threats expressed by large loan capacity and / or fund availability. The credibility of expected threat of retaliation is measured by: (1) Financial leverage, defined as net financial obligations divided by common stockholders' equity; (2) Excess Funds (ExFunds), defined as net financial assets divided by net operating assets (NOA).

Competitive advantage will encourage companies to achieve superior performance (Agha et al., 2011; Chahal and Bakshi, 2014; Fahy et al., 2004; Gaya et al., 2013; Li et al., 2006). Grant (1991) stated that competitors competitive advantage determine the company's profitability. Rochdi, et al. (2017) suggests that an innovative company will have a competitive advantage that affects financial performance. Based on the Resources Based View (RBV), the superior performance of companies that have competitive advantage is due to meet the criteria of valuable, rareness, inimitable, and non-substitutability. Powell and Dent-micallef (1997) and Cao et al. (2014) suggested that the competitive advantage will improve the financial performance of the company, not vice versa. Based on this framework, we formulate hypothesis as follow:

Hypothesis 1: Competitive Advantage has a significant effect on the Financial Performance.

Studies about the effect of competitive advantage on firm value are rare. Standfield (2005) states that the competitive advantage can increase the market value, share price, earnings, and revenue. According to signaling theory, the company will send a positive signal to investors and other stakeholders in order to respond positively to higher stock prices (Connelly et al., 2011). Based on the theory of signaling, high enterprise competitive advantage will demonstrate the company's current situation and the potential for growth in the future. The positive signal will increase stock prices and so contribute positively on firm value. Based on this framework, we formulate hypothesis as follow:

Hypothesis 2: Competitive Advantage has a significant effect on Firm Value

Financial Performance. Performance is defined as a result of the organizational activity or investment over a given period of time. Neeley et al. conceptualize performance as a process of quantifying the efficiency and effectiveness of an action (Chahal and Bakshi, 
2014). Financial performance refers to measures that show the achievement of financial goals by the company.

Firm performance measurement can be done through two approaches, Market performance and or Financial performance (Vanpoucke, Vereecke, \& Wetzels, 2014). Market performance is measured using market share and sales growth; earnings per share (Gherghina \& Simionescu, 2015). Financial performance is measured using return on sales (ROS) and return on investment (ROI); return on assets (ROA) and return on equity (ROE) (Felício, et al., 2012; Gherghina \& Simionescu, 2015); Asset turnover (Bashir, et al., 2013). Cabrita and Vaz (2006) and Chahal and Bakshi (2014) states that the measurement of financial performance can be executed both quantitatively and qualitatively. Quantitatively, performance measurement focuses on financial measures such as ROA, ROE, and ROI as well as nonfinancial aspect. Qualitatively, financial performance is measured perceptually against various stakeholders on various aspects.

Based on signaling theory, the financial performance of Companies will show the current state of the company and the potential for growth in the future. The positive signal that can be seen from the profitability of the company will be able to enhance the company's stock price so as to contribute positively to firm value. Ghosh and Ghosh (2008) stated that the profitability as an indicator of financial performance becomes one of the main factors that determine firm value. Past research in this path shows the different findings. Significant effect of financial performance on firm value is shown in research of (Chen and Chen, 2011; Ghosh and Ghosh, 2008; Nuryaman, 2015; Sudiyatno et al., 2012; Wang, 2014). Based on this framework, we formulate hypothesis as follow:

Hypothesis 3: Financial Performance has a significant effect on firm value

Firm Value. Firm value show total market value of a business. Firm Value will be reflected from the stock market price. The value of the firm indicates the price that potential buyers are willing to pay if the company is sold.

Firm value can be measured using several indicators. Tobin's $Q$ ratio has been widely used by researchers to measure firm value. Tobin's $Q$ ratio is ratio between the Firm's Total Market Value divided by Book Value of Total Assets (Chung and Pruitt, 1994). Other measuring tools of firm value are the Market Value of Equity (MVE) and Market to Book Value Ratio (MBVR) (Ghosh and Ghosh, 2008). MVE is the total of the outstanding stock market value. MVE is calculated by the Shares outstanding formula multiplied by Stock price (Ehrhardt \& Brigham, 2011). MBVR is the ratio between the stock market price and the book value of shares. MBVR is calculated by dividing the Closing Price of The Equity by its Book Value of Equity (Ghosh \& Ghosh, 2008).

\section{METHODS OF RESEARCH}

Sample and Data. The population in this study was all manufacturing companies listed on the Indonesia Stock Exchange (IDX) in the period 2010 to 2016. The sampling technique was purposive. Samples are taken based on the following criteria: (a) Manufacturing companies listed on the IDX and publish annual financial statements during the period 20102016 respectively; (b) Disclose $R$ \& D activities in its financial statements. It is important because $R$ \& $D$ activities show that the company is innovating to achieve competitive advantage (Dickinson and Sommers, 2012). Based on these criteria, the sample is determined as 30 companies. The data obtained from Indonesian Capital Market Directory (ICMD), the company's financial report, annual report, performance summary, and IDX Facts Book.

Variables and Measurements. Variables in this study are grouped into exogenous and endogenous variables. The exogenous variables was Competitive Advantage (X), while the endogenous variables were Financial Performance (Y1) and Firm Value (Y2).

Competitive Advantage measured using indicators formulated by Dickinson and Sommers (2012), include: (1) Economies of scale measured by the ratio of Cost of Sales (CoS), the ratio between Cost of Goods Sold divided by Net sales; (2) Innovation measured by The Innovation (Innov) ratio, the ratio between R\&D expense plus Patent amortization 
expense divided by Net sales; (3) Capital requirements measured by Capital intensity (Caplnt), the ratio between depreciation expenses divided by net sales; (4) Power over suppliers measured by Operating Liability Leverage (OLLev), the ratio between Operating Liabilities divided by Net Operating Assets, and Inventory Turnover (ITO), the ratio between Cost Of Goods Sold divided by Inventory; (5) Power over customers measured by Receivables Turnover (RTO), the ratio between Net Sales divided by Receivables, Market share (MS), the ratio between Sales Revenue divided by Total Sales Revenues Industry; (6) The credibility of the expected threat of Retaliation measured by Financial leverage (FLev), the ratio between Net Financial Obligations divided by Common Stockholders' Equity, and Excess Funds (ExF), the ratio between Net Financial Assets divided by Net Operating Assets. Advint ratio was not used because there is no separation between advertising costs and other promotional costs in the company's financial statements in Indonesia.

Financial Performance (Y1) measured by Return on Asset (ROA), Return on Equity (ROE), and Asset Turnover (ATO) (Berrone, et al., 2007; Dubey \& Chakrabarty, 2011). ROA is the ratio between net profits after taxes to total assets (Horne, 2002). ROA indicates a company's ability to use total assets in generating net income. ROE is the ratio between net earnings to stockholders equity. ROE indicates a company's ability to use equity in generating net income. ATO is the ratio between sales to total assets. ATO show the company's ability to use its total assets to generate revenue (Higgins, 2009).

Firm Value (Y2) measured by Tobin's Q, Market Value of Equity (MVE) and market to book value ratio (MBVR). Ratio Tobin's $Q$ formulated by Chung and Pruitt (1994) divides the Firm's Total Market Value (MVE+preferred stock+Total Debt) by Book Value of Total Assets. MVE is the total of the outstanding stock market value. MVE was measured using the formula Shares outstanding $x$ Stock price (Ehrhardt and Brigham, 2011). MBVR is the ratio of closing equity prices to book value equity at the end of the financial year (Ghosh and Ghosh, 2008).

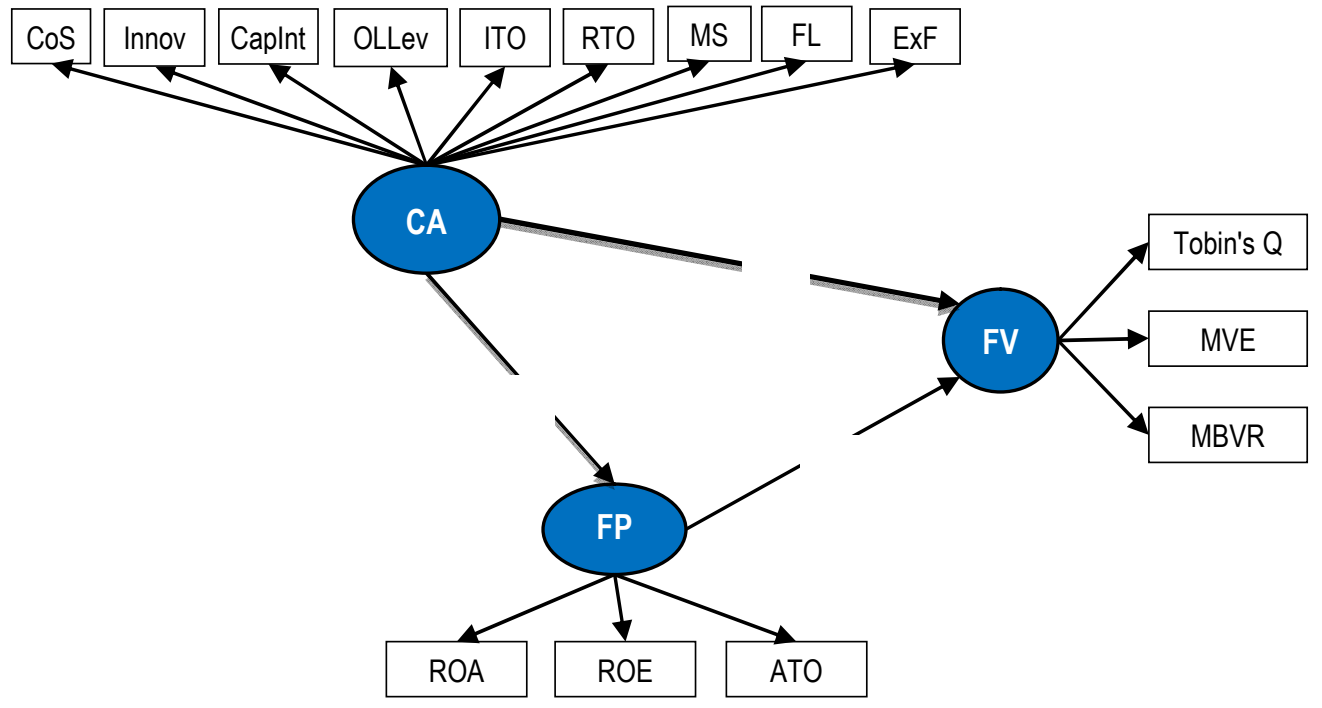

Figure 1 - Research Framework

Description: $C A$ = Competitive Advantage; $\operatorname{CoS}=$ Cost of Sales; Innov = Innovation ratio; Caplnt = Capital intensity; OLLev = Operating Liability Leverage; ITO = Inventory Turnover; RTO = Receivables Turnover; $M S=$ Market share; FL = Financial leverage; ExF = Excess Funds; FP = Financial Performance; $R O A=$ Return On Asset; $R O E=$ Return On Equity; $A T O=A s s e t$ Turnover; FV = firm value; $M V E=$ Market Value of Equity; $M B V R=$ Market to Book Value Ratio

Statistical Analysis. The data analysis was conducted using Generalized Structured Component Analysis (GSCA). GSCA is An analysis technique developed by Hwang and Takane (2015) with the approach of maximizing the average or number of variants for linear composites. The GSCA can be applied to a variety of studies because of the following advantages: it does not require normality assumptions, can be run with small sample quantities, avoids the problem of negative-value variance, yields a unique estimation useful 
for further estimation, provides overall model fit for testing theory and model comparison, as well as having combined characteristics between CB-SEM and PLS-SEM (Hwang \& Takane, 2004; Latan, 2014). The research framework shown in Figure 1.

\section{RESULTS AND DISCUSSION}

The results of descriptive statistics analysis are shown in Table 1. The firms show good efficiency levels, indicated by the mean cost of sales ratio $>1$. Company spending on innovation activities is quite low with an average of $0.38 \%$. ITO ratio is quite high, which is 7.19 times. This shows the company has a strong position of negotiation advantage over the supplier. Power over customers is moderate with average RTO 10.11 times. On average the company has a market share of $12.84 \%$ in each industry. Indonesian manufacturing firms also have good capabilities for debt (Average Flev $=0.0554$ ) and excess funds to perform retaliation (Average ExF $=0.3905$ ).

Manufacturing companies in Indonesia also show good financial performance. This is indicated by the average positive ROA and ROE, respectively 0.0905 and 0.1563 . Average sales are also recorded larger than the total assets (Average ATO $=1.3662$ times).

The average value of firm value in manufacturing companies in Indonesia is high. This can be seen from the average value of Tobin's $Q$ of 2.4678. The value of Tobin's $Q>1$ describes overvalued conditions in stocks, successful asset management, and high investment growth potential (Sudiyatno et al., 2012). In line with the $Q$ value, the average MBV ratio indicates that the firm's stock market price is 3.35 times to its book value.

Table 1 - Descriptive Statistics

\begin{tabular}{|c|c|c|c|c|c|c|c|}
\hline Variabel & Indicator & $\mathrm{N}$ & Min & Max & Median & Mean & Standard Deviation \\
\hline \multirow{5}{*}{ Competitive Advantage } & CoS & 203 & 0.8863 & 3.0995 & 1.3039 & 1.4375 & 0.4014 \\
\cline { 2 - 8 } & Innov & 203 & 0.0000 & 0.1037 & 0.0012 & 0.0038 & 0.0094 \\
\cline { 2 - 8 } & Caplnt & 203 & 0.0008 & 0.1299 & 0.0195 & 0.0235 & 0.0169 \\
\cline { 2 - 8 } & OLLev & 203 & -3.0380 & 5.1379 & 0.2142 & 0.3357 & 0.6481 \\
\cline { 2 - 8 } & ITO & 203 & 1.2288 & 92.9091 & 4.4671 & 7.1960 & 12.3636 \\
\cline { 2 - 8 } & RTO & 203 & 0.9874 & 82.1845 & 7.3746 & 10.1147 & 12.4526 \\
\cline { 2 - 7 } & MS & 203 & 0.0000 & 0.5262 & 0.0526 & 0.1284 & 0.1580 \\
\cline { 2 - 7 } & Flev & 203 & -5.5967 & 5.8404 & -0.0378 & 0.0554 & 1.0377 \\
\cline { 2 - 7 } & ExF & 203 & -2.5938 & 2.9761 & 0.3054 & 0.3905 & 0.4847 \\
\hline \multirow{5}{*}{ Financial Performance } & ROA & 203 & -0.2223 & 0.4165 & 0.0815 & 0.0905 & 0.0948 \\
\cline { 2 - 7 } & ROE & 203 & -1.1817 & 1.6313 & 0.1458 & 0.1563 & 0.1993 \\
\cline { 2 - 7 } & ATO & 203 & 0.2855 & 8.4293 & 1.2238 & 1.3662 & 0.9230 \\
\hline \multirow{5}{*}{ Firm Value } & MVE & 203 & 9.2301 & 19.9068 & 1.5097 & 14.8175 & 2.4333 \\
\cline { 2 - 7 } & Q & 203 & 0.5332 & 11.6645 & 1.7250 & 2.4678 & 2.0521 \\
\cline { 2 - 7 } & MBVR & 203 & -2.7000 & 25.8000 & 2.2900 & 3.3507 & 3.7243 \\
\hline
\end{tabular}

Furthermore, an inferential analysis was conducted to test the research hypothesis. The analysis was performed using GSCA (Generalized Structured Component Analysis). The result of data analysis using Software GeSCA is shown in Table 2. Table 2 shows that the FIT value is 0.373 . This value indicates the total variance of the observed variables explained by the model is 37.3 percent.

Table 2 - Goodness if Fit and Path Coefficients

\begin{tabular}{|c|c|c|c|c|c|c|c|}
\hline \multicolumn{2}{|c|}{ Model Fit } & \multicolumn{2}{c|}{ R square } & Path & Estimate & $\begin{array}{c}\text { Standard } \\
\text { Errors }\end{array}$ & $\begin{array}{c}\text { Critical } \\
\text { Ratio }\end{array}$ \\
\hline FIT & 0.373 & CA & 0 & CA->FP & 0.651 & 0.043 & $15.06^{*}$ \\
\hline AFIT & 0.370 & FP & 0.423 & CA->FV & 0.570 & 0.101 & $5.67^{*}$ \\
\hline NPAR & 18 & FV & 0.697 & FP->FV & 0.343 & 0.143 & $2.4^{*}$ \\
\hline
\end{tabular}

$C R^{*}=$ significant at .05 level, CA: Competitive Advantage, FP: Financial Performance, FV: firm value, AFIT: Adjusted FIT, NPAR: Non parametric test. 
The bootstrapping calculation process shows that the critical ratio value of competitive advantage variable to financial performance is $15.06>1.96$ (sig. level $=5 \%$ ). This proves the significance of competitive advantage's effect on financial performance. Thus, hypothesis $\mathrm{H} 1$ is accepted. Competitive Advantage positively affects the financial performance with an estimate value of 0.651 .

The critical ratio value of competitive advantage variable to firm value is $5.67>1.96$. This proves the significance of competitive advantage effect on firm value, hypothesis $\mathrm{H} 2$ accepted. Competitive Advantage positively affects the firm value with an estimate value of 0.570. Competitive Advantage can explain the variability of financial performance of 42.3 percent.

The critical ratio value of the influence of the financial performance variable to firm value is $2.4>1.96$. This proves the significance of the effect of financial performance on firm value, the hypothesis $\mathrm{H} 3$ accepted. Financial Performance positively affects the firm value with an estimate value of 0.343 . Competitive Advantage and financial performance can explain the variability of firm value of 69.7 percent.

The results show that the effect of competitive advantage to firm value is greater than the effect of financial performance on firm value. This shows a greater investor response to the company's competitive efforts than financial performance. The company's position in the competition seen as important for investors.

The significance of competitive advantage's influence on financial performance confirms Grant's (1991) statement that one of the determinants of corporate profitability is competitive advantage. The results of this study also support the findings of Newbert (2008); Gamero, et al. (2009); Kamukama, et al. (2011); Sungyuan \& Ussahawanitchakit (2015); and Zhou, et al. (2009) who proves a positive and significant relationship between competitive advantage and Financial Performance.

The second conclusion of this study provides new evidence that competitive advantage has a significant effect on firm value. Based on signaling theory, the information contained in the financial statements is a signal that can affect firm value (Connelly et al., 2011). As the measurements used in the study, information about the company's competitive advantage position can be extracted from the financial statements.

The significance of the effect of financial performance on firm value also provides empirical support for signaling theory. Financial performance is one of the main factors which determines firm value (Ghosh and Ghosh, 2008). Profitability of the company is a positive signal that will increase the company's stock price.

The implication of the findings of this research is that firms must have competitive advantage and better financial performance to increase firm value. Competitive Advantage and financial performance become positive signals regarding the current condition of the company and its prospects in the future. Build competitive advantage not only rely on the advantages based on geographical factors, but based on the internal strength of the company itself both the resources-based and non-resources based. Companies must create barriers to entry through economies of scale, product differentiation, innovation and high capital requirements. In addition, the company must have an advantage over suppliers, customers, and the ability to take retaliatory action.

\section{CONCLUSION}

The importance of developing a competitive advantage for the company has been widely studied by various researchers. Having a high competitive advantage plays an important role for both companies to achieve financial performance (Grant, 1991) and higher firm value (Standfield, 2005). The aim of the present research was to examine the effect of competitive advantage on financial performance and firm value of manufacturing firms in Indonesia. For that purpose, we used panel data from 30 public manufacturing firms in Indonesia from 2010 to 2016. The data then analyzed using GSCA. This research proves that competitive advantage has a significant effect to financial performance and firm value. The research has also shown that financial performance has a significant effect to firm value. 
The evidence from this study suggests that it is important for a company to have a competitive advantage. Competitive advantage not only positively affects financial performance but also higher corporate value.

The limitation of this study is that few manufacturing firms disclose the $R \& D$ expenditure in their financial statements. Future research can expand the sample on innovative service companies. The effect of competitive advantage on firm value is rarely getting the previous review. Further research on the influence of competitive advantage on firm value needs to be done to obtain strong empirical evidence. The role of the financial performance as a mediator on the relationship between competitive advantage and firm value needs to be further proven.

\section{REFERENCES}

1. Agha, S., Alrubaiee, L., \& Jamhour, M. (2011). Effect of Core Competence on Competitive Advantage and Organizational Performance. International Journal of Business and Management, 7(1), 192-205. https://doi.org/10.5539/ijbm.v7n1p192

2. Barney, J. (1991). Firm Resources and Sustained Competitive Advantage. Journal of Management, 17(1), 99-120.

3. Bashir, T., Riaz, A., Butt, S., \& Parveen, A. (2013). Firm Performance: A Comparative Analysis Of Ownership Structure. European Scientific Journal, 9(31), 413-431.

4. Berrone, P., Surroca, J., \& Tribó, J. A. (2007). Corporate ethical identity as a determinant of firm performance: A test of the mediating role of stakeholder satisfaction. Journal of Business Ethics, 76(1), 35-53. https://doi.org/10.1007/s10551-006-9276-1

5. Boasson, V., Boasson, E., MacPherson, A., \& Shin, H. H. (2005). Firm Value and Geographic Competitive Advantage: Evidence from the U.S. Pharmaceutical Industry. The Journal of Business, 78(6), 2465-2495. https://doi.org/10.1086/497038

6. Cabrita, R., \& Vaz, J. L. (2006). Intellectual Capital and Value Creation: Evidence from the Portuguese Banking Industry. Electronic Journal of Knowledge Management, 4(1), 11-20. https://doi.org/10.1111/j.1755-0998.2011.03037.x

7. Cao, D., Berkeley, N., \& Finlay, D. (2014). Measuring Sustained Competitive Advantage From Resource-based View: Survey of Chinese Clothing Industry. Journal of Sustainable Development, 7(2), 89-104. https://doi.org/10.5539/jsd.v7n2p89

8. Chahal, H., \& Bakshi, P. (2014). Effect of intellectual capital on competitive advantage and business performance: Role of innovation and learning culture. International Journal of Learning and Intellectual Capital, 11(1), 52-70. https://doi.org/10.1504/IJLIC.2014.059227

9. Chen, L. J., \& Chen, S. Y. (2011). The influence of profitability on firm value with capital structure as the mediator and firm size and industry as moderators. Investment Management and Financial Innovations, 8(3), 121-129.

10. Chung, K. H., \& Pruitt, S. W. (1994). A simple approximation of Tobin's Q. Financial Management, 70-74.

11. Coff, R. W. (1999). When Competitive Advantage Doesn't Lead to Performance: The Resource-Based View and Stakeholder Bargaining Power. Organization Science, 10(2), 119-133. https://doi.org/10.1287/orsc.10.2.119

12. Connelly, B. L., Certo, S. T., Ireland, R. D., \& Reutzel, C. R. (2011). Signaling Theory: A Review and Assessment. Journal of Management, 37(1), 39-67. https://doi.org/10.1177/0149206310388419

13. Deloitte and US Council on Competitiveness. (2016). 2016 Global Manufacturing Competitiveness Index. Washington.

14. Dickinson, V., \& Sommers, G. A. (2012). Which competitive efforts lead to future abnormal economic rents? Using accounting ratios to assess competitive advantage. Journal of Business Finance and Accounting, 39(3-4), 360-398. https://doi.org/10.1111/j.1468-5957.2012.02283.x

15. Dubey, R., \& Chakrabarty, A. (2011). Role of Innovative Supply Chain Practices and Total Quality Management (TQM) on Performance of Indian Cement Manufacturing Firms 
-An Empirical Study. Polish Journal of Management Studies, 4, 96-119.

16. Ehrhardt, M. C., \& Brigham, E. F. (2011). Corporate Finance: A Focused Approach (Fourth). Mason: South-Western. https://doi.org/10.1017/CBO9781107415324.004

17. Fahy, J., Farrelly, F., \& Quester, P. (2004). Competitive advantage through sponsorship: A conceptual model and research propositions. European Journal of Marketing, 38(8), 1013-1030. https://doi.org/10.1108/03090560410539140

18. Felício, J. A., Rodrigues, R., \& Caldeirinha, V. R. (2012). The effect of intrapreneurship on corporate performance. Management Decision, 50(10), 1717-1738. https://doi.org/10.1108/00251741211279567

19. Gamero, M. D. L., Azorín, J. F. M., \& Cortés, E. C. (2009). The whole relationship between environmental variables and firm performance: Competitive advantage and firm resources as mediator variables. Journal of Environmental Management, 90(10), 31103121. https://doi.org/10.1016/j.jenvman.2009.05.007

20. Gaya, H. J., Struwig, M., \& Smith, E. E. (2013). Creating a sustainable competitive advantage at a high performing firm in Kenya. African Journal of Business Management, 7(21), 2049-2058. https://doi.org/10.5897/AJBM2013.6974

21. Gherghina, S. C., \& Simionescu, L. N. (2015). Does Entrepreneurship and Corporate Social Responsibility Act as Catalyst towards Firm Performance and Brand Value? International Journal of Economics and Finance, 7(4), 23-35. https://doi.org/10.5539/ijef.v7n4p23

22. Ghosh, S., \& Ghosh, A. (2008). Do Leverage, Dividend Policy and Profitability influence the Future Value of Firm? Evidence from India. Policy, (July). Retrieved from http://ssrn.com/abstract=1158251

23. Grant, R. M. (1991). The Resource-Based Theory of Competitive Advantage: Implications for Strategy Formulation. California Management Review, 33(3 SRC-GoogleScholar FG0), 3-23. https://doi.org/10.2307/41166664

24. Higgins, R. C. (2009). Analysis for Financial Management (Tenth Edit). New York: McGraw-Hill Companies, Inc.

25. Horne, J. C. Van. (2002). Financial management and policy (12 ed.). New Jersey: Prentice Hall, Inc.

26. Hwang, H., \& Takane, Y. (2004). Generalized structured component analysis. Psychometrika, 69(1), 81-99. https://doi.org/10.1007/BF02295841

27. Hwang, H., \& Takane, Y. (2015). Generalized structured component analysis: A component-based approach to structural equation modeling. Boca Raton: CRC Press.

28. Kaczmarek, J. (2014). Measurement Of Creating Corporate Value For Shareholders Development Of Measurements and Improvement Of Management Competence And Skills. Polish Journal of Management Studies, 9, 72-83.

29. Kamukama, N., Ahiauzu, A., \& Ntayi, J. M. (2011). Competitive advantage: mediator of intellectual capital and performance. Journal of Intellectual Capital, 12(1), 152-164. https://doi.org/10.1108/14691931111097953

30. Latan, H. (2014). Teori, Konsep, dan Aplikasi Menggunakan GeSCA. Bandung: Sarana Tutorial Nurani Sejahtera.

31. Li, S., Nathan, B. R., Nathan, T. S. R., \& Rao, S. S. (2006). The impact of supply chain management practices on competitive advantage and organizational performance. The International Journal of Management Science, 34, 107-124. https://doi.org/10.1016/j.omega.2004.08.002

32. Meutia, \& Ismail, T. (2012). The Development of Entrepreneurial Social Competence and Business Network to Improve Competitive Advantage and Business Performance of Small Medium Sized Enterprises: A Case Study of Batik Industry in Indonesia. Procedia Social and Behavioral Sciences, 65(ICIBSoS), 46-51. https://doi.org/10.1016/j.sbspro.2012.11.089

33. Newbert, S. L. (2008). Value, Rareness, Competitive Advantage, And Performance: A Conceptual-Level Empirical Investigation Of The Resource-Based View Of The Firm. Strategic Management Journal, 29, 745-768. https://doi.org/10.1002/smj

34. Nuryaman. (2015). The Influence of Intellectual Capital on The Firm's Value with The 
Financial Performance as Intervening Variable. Procedia - Social and Behavioral Sciences, 211(September), 292-298. https://doi.org/10.1016/j.sbspro.2015.11.037

35. Peteraf, M. A. (1993). The Cornerstones of Competitive Advantage: A Resource-Based View. Strategic Management Journal, 14(3), 179-191.

36. Porter, M. E. (1980). Competitive strategy: techniques for analyzing industries and competitors (First Edit). New York: Free Press. https://doi.org/10.1017/CBO9781107415324.004

37. Porter, M. E. (1985). Competitive Advantage: Creating and Sustaining Superior Performance (First). New York: The Free Press.

38. Powell, T. C., \& Dent-micallef, A. (1997). Information Technology As Competitive Advantage: the Role of Human, Business, and Technology Resources. Strategic Management Journal, 18(5), 375-405.

39. Rochdi, D., Khatijah, O., \& Muhammad, A. S. A. H. (2017). Mediating Role of the Innovation Effectiveness on the Relationship Between Entrepreneurial. Polish Journal of Management Studies, 15(1), 185-196. https://doi.org/10.17512/pjms.2017.15.1.18

40. Standfield, K. (2005). Intangible Finance Standards: Advances In Fundamental Analysis \& Technical Analysis. Journal of Chemical Information and Modeling (Vol. 53). Burlington: Elsevier Inc. https://doi.org/10.1017/CBO9781107415324.004

41. Sudiyatno, B., Puspitasari, E., \& Kartika, A. (2012). The Company's Policy, Firm Performance, and Firm Value: An Empirical Research on Indonesia Stock Exchange. American International Journal of Contemporary Research, 2(12), 30-40. Retrieved from http://www.aijcrnet.com/journals/Vol_2_No_12_December_2012/4.pdf

42. Sungyuan, T., \& Ussahawanitchakit, P. (2015). Dynamic organizational capability and firm success: an empirical investigation of cosmetic businesses in Thailand. The Business and Management Review, 7(1), 53-66.

43. Vanpoucke, E., Vereecke, A., \& Wetzels, M. (2014). Developing supplier integration capabilities for sustainable competitive advantage: A dynamic capabilities approach. Journal of Operations Management, 32(7-8), 446-461. https://doi.org/10.1016/j.jom.2014.09.004

44. Wang, C. J. (2014). The Impact of Macroeconomic and Corporate Governance Factors on Firm Value of Taiwanese Green Technology Industry: A Consideration of Differential Slope. International Journal of Economics and Finance, 6(7), 157-165. https://doi.org/10.5539/ijef.v6n7p157

45. Wernerfelt, B. (1984). A resource-based view of the fir. Management Journal, 5(2), $171-$ 180. https://doi.org/10.1002/smj.4250050207

46. Zhou, K. Z., Brown, J. R., \& Dev, C. S. (2009). Market orientation, competitive advantage, and performance: A demand-based perspective. Journal of Business Research, 62(11), 1063-1070. https://doi.org/10.1016/j.jbusres.2008.10.001 